\title{
The Travails of Doing Labor History: The Restless Wanderings of John Womack Jr.
}

\author{
John D. French and Daniel James
}

"Thi his is a book about country people who did not want to move and therefore got into a revolution. They did not figure on so odd a fate." With this pithy observation, John Womack Jr. opened his 1969 book Zapata and the Mexican Revolution. Nominated for the National Book Award in 1970, Zapata has been read by tens of thousands, and its author, while still in his early thirties, was awarded the Robert Woods Bliss Chair in Latin American History and Economics at Harvard University, where he had received his B.A. and his Ph.D. ${ }^{1}$ Academically, his inaugural monograph sparked a turn toward grass-roots regional studies of the Mexican Revolution. Beyond the Mexicanist field, Zapata helped to inspire the new agrarian social and political history that flourished among English-speaking Latin Americanists in the I97os and it continued to win wide praise, even from Mexican novelist Carlos Fuentes.

Colleagues from around the country were very helpful as we grappled with the Womack article, and we received useful suggestions from a number of junior scholars and graduate students. Among the many established scholars we would especially like to thank Chuck Bergquist, Jeff Cowie, Leon Fink, and Peter Guardino for their comments. Reeve Huston and David McCreery also provided helpful written evaluations of an earlier version of this essay at the Twenty-third Annual Latin American Labor History Conference (LALHC) at Duke University. In its final form, this article also benefited from the vigorous discussion among the conference participants on May 5-6, 2006. To communicate with the authors, contact jdfrench@ duke.edu ordajames@indiana.edu.

I. John Womack Jr., Zapata and the Mexican Revolution (New York: Knopf, I969), I; "[Robert] Lowell, Womack Are Considered for Two National Book Awards," Harvard Crimson, February 28, i97o. He did his 1959 undergraduate thesis on an agrarian theme from his home state: "Oklahoma's Green Corn Rebellion: The Importance of Fools.” After a Rhodes scholarship 1959-1962, he entered the doctoral program in History and defended his dissertation in 1966 on "Emiliano Zapata and Revolution in Morelos, I9I0-I920." Hired directly at Harvard as an assistant professor, he was named to the Bliss chair in I970I97I. Robert Wood Bliss was U.S. Ambassador to Argentina before World War I and was sent to Paris in the aftermath. "The contemplation of the damages caused by the war made him believe that the future of civilization was in the Americas," and the chair was formally created in $1922-23$ and held by Clarence Haring until the early I950s (Private e-mail communication from Ricardo Salvatore, January 20, 2006).

Labor: Studies in Working-Class History of the Americas, Volume 4, Issue 2

DOI 10.1215/15476715-2006-067 $\quad$ C 2007 by Labor and Working-Class History Association 
While the generation of the I970s turned to the rural, John Womack embarked upon research on the then-neglected subject of urban workers ${ }^{2}$ with a project on the state of Veracruz, whose labor struggles were central to the myth and trajectory of the Mexican Revolution. Although Womack was described as "concluding his decade-long study" in $1979,{ }^{3}$ twenty years passed before he published an article on any aspect of the project; ${ }^{4}$ this was followed six years later by an essay published in the fall 2005 issue of the Journal of the Historical Society $(J H S)$. As the title of the essay suggests, "Doing Labor History: Feelings, Work, Material Power" ranges far beyond Veracruz while offering Womack's assessment of the state of labor history. ${ }^{5}$ In truth, this impassioned philippic registers a strident dissent from what he deems to be the erroneous direction of all labor history done since the ig6os in Europe, the United States, and Latin America. ${ }^{6}$

At the time that Womack's silence came to an end, most Latin Americanists were unaware of his labor history interests, even though his scholarly stature was secure given his acclaimed first book, his reputation as a Marxist, and the prestige of Harvard University, where he has twice chaired the history department. He had published far less than others of his generation but was nonetheless widely admired for his early historiographical reviews, ${ }^{7}$ a 1999 document collection, ${ }^{8}$ and his articles in the New York Review of Books and the New Republic. Less enthusiasm was generated by his ubiquitous and often opinionated book reviewing. Yet his book blurbs were still sought, and his name often appeared on petitions in support of progressive causes. For those of us involved in Latin American labor history, Womack's project was known

2. The political context for the boom in the study of rural social struggles, and the late shift to urban labor is discussed in John D. French, "The Latin American Labor Studies Boom." International Review of Social History [Amsterdam] 45, no. 2 (2000): 280.

3. Rodney A. Anderson, "Comentario," in Labor and Laborers through Mexican History, ed. Elsa Cecília Frost, Michael C. Meyer, Josefina Zoraída Vázquez, and Lílía Díaz (Mexico/Tucson: El Colegio de México/University of Arizona Press, I979), 731.

4. John Womack Jr., "Work in the Moctezuma Brewery," in Reconstructing History: The Emergence of a New Historical Society, ed. Elizabeth Fox-Genovese and Elisabeth Lasch-Quinn (New York: Routledge, I999), 347-6o.

5. John Womack Jr., "Doing Labor History: Feeling, Work, Material Power," Journal of the Historical Society 5, no. 3 (2005): 255-96. A March I7, 2005, lecture in Mexico City by Womack, sponsored by the Asociación Mexicana de Historia Económica y la Facultad de Economía-UNAM, had the title "Prolegómeno para una nueva historia obrera."

6. Although a specialist on Latin America, Womack's endnotes suggest a North Atlantic focus in the labor history field with an overwhelming concentration on intellectual production in the United States and, to a lesser extent, Europe with Latin America coming in a very distant third.

7. The most influential of three such articles by Womack was "The Mexican Economy during the Revolution, I910-I920: Historiography and Analysis," Marxist Perspectives I, no. 4 (I978): 80-I23.

8. The unique blend of attention to detail, thick description, and empathy that marked his inaugural monograph would also be found in the introduction to a document collection he edited thirty years later about a new movement, in Chiapas, that took the name of Emiliano Zapata as their own in honor of the martyred peasant revolutionary. John Womack Jr., Rebellion in Chiapas: An Historical Reader (New York: New Press, 1999). 
primarily through a I979 essay that sketched out his version of total labor history (it was cited by the authors of this article in the introduction to a 1997 edited collection). ${ }^{9}$ With the passing of years and then decades, it was apparent that something was amiss because nothing, however preliminary, was shared with those who were striving to open up the emerging field of Latin American labor history.

When his forty-one-page historiographical essay appeared in JHS, its form and spirit - a highly personalized narrative line with a penchant for pungent opinions - surprised many. All in all, this densely written article, accompanied by ninetysix footnotes citing hundreds of books and articles, is a disjointed and conflicted text by a scholar unpublished in the field. As such, the JHS piece might seem an unlikely subject for detailed analysis were it not for the respect earned by Womack's past contributions and our concern that his personal prestige, and the symbolic capital of his Harvard position, were being used to disseminate a tendentious rendering of the labor history field.

This article begins by dissecting the historiographical account offered by Womack, who tells a story of an early romance followed by his subsequent disillusionment. This section also criticizes Womack's resort to ad hominem attacks and other irresponsible argumentative ploys. In the second section, we focus on the peculiarly confessional dimension of Womack's 2005 essay, which we characterize as a failed bildungsroman. From there, we offer a diagnosis of the impasse that has stymied Womack's multidecade study of Veracruz. In particular, we compare his selfrepresentation in the $J H S$ article, in which he figures centrally as a character, with what can be proven based on his scholarly and journalistic publications, interviews, and newspaper reports since the I96os. In so doing, we offer an alternate account of his predicament as it touches on larger scholarly controversies about representation, the role of narrative and culture, and epistemological debates about historical causality. Throughout, we follow an ethics of responsible reading that avoids ad hominem argument through an exclusive reliance on direct evidence derived from the close reading and citation of relevant sources.

\section{John Womack and Labor History: From Youthful Romance to the Practiced Bad Habits of the Veteran}

To understand Womack's historiographical intervention, one must begin with his decision to eschew the impersonal third person that often characterizes the genre. Instead, he makes himself a character in a story line that begins with his romance with labor history in the late ig6os, when "giants of several kinds ruled the field.... Above all [E. P.] Thompson ... [and] whatever influence they accepted, the young all took their subject in Thompson's spirit to be workers' subjectivity, 'agency.",10 At the

9. John Womack Jr., “The Historiography of Mexican Labor,” in Frost et al. eds., Labor and Laborers, 739-56; John D. French and Daniel James, "Squaring the Circle: Women’s Factory Labor, Gender Ideology, and Necessity," in The Gendered Worlds of Latin American Women Workers, ed. John D. French and Daniel James (Durham, NC: Duke University Press, 1997), I-30.

Io. Womack, "Doing," 273. 
beginning, he says that he dutifully set out to use the workers' "culture to explain their politics, ... but the more I learned ... the less Thompson helped me to understand it." ${ }^{\prime 1}$ The JHS narrative of his Veracruz research is interwoven with an account of his gradual disappointment with a field to which he hoped to contribute. If his declared admiration for labor history seems somewhat faux, the 2005 essay gains momentum as he descends toward the sarcasm and condescension that mark the depths of his disillusionment. While mocking "established old American masters of labor history, following Saint Edward [E. P. Thompson] and Saint Herb [Herbert Gutman]," his scorn extends to figures marginal to the academic labor history field, including two identical dismissals of oral history narratives from "the venerable Ronald Fraser and blessed Studs Terkel."12

The declared focus of the JHS essay is the idea of "strategic position" in industry, a classic theme that has generated a vast body of research across several generations. In this part of the piece, Womack parses his differences with the books and articles of other scholars, none of whom gain his approval. At his most exacting, Womack distinguishes between his concern with the "technical" and those who analyze strategic positions as part of “'social relations' or a 'socially constructed' relationship or 'social practice' at work. This was still social history, sociology, which was essential but not engineering. I wanted to conceptualize the engineering of social production, the mechanics of it, the forces and motion in it."13 To outsiders, Womack's drawing of fine distinctions may seem arcane, although labor history practitioners are more likely to wonder about his failure to fully engage, other than in passing, with David Montgomery's research in the I970s on changing machine technology, strategic skills, and working-class praxis. As for his declared aspirations, labor history practitioners may be somewhat impatient with Womack's depiction of himself, standing alone in lofty rectitude, arrayed against other lesser scholars whose claims can be judged based on their published work. Finally, Womack identifies a surprising alternative inspiration for what he now calls his technical history of work: John Dunlop, a key founder of the discipline of industrial and labor relations in the United States since World War II.

Yet technical issues involving industrial labor do not produce Womack's fire and passion, which largely derives from the hothouse atmosphere of the U.S. academic Kulturkampf of the I980s and I99os. Womack is particularly contemptuous of the institutional venues and scholars involved in current attempts to reinvigorate the labor history field, including the Labor and Working Class History Association, the North American Labor History Conference, Labor: Studies in Working Class History of the Americas, and an edited book by the authors of this article. ${ }^{14}$ In Womack's

II. Womack, "Doing," 258, 256.

I2. Womack, "Doing," 268, 26I (the dig about "the venerable Fraser or blessed Studs" is repeated on 267).

I3. Womack, "Doing," 263

I4. Womack, "Doing," 268-270, 292n62. A discussion of the declining appeal of labor history to the general U.S. public is sarcastically attacked by Womack as a "notion (eventually expressed at an Organi- 
account, labor history is mired in an intellectually unsound and politically motivated attempt to "practically redefine the field as a general history of injustice" by those who still see the world through the lens of Robin Hood versus the Sheriff of Nottingham. ${ }^{15}$ After suggesting an academic pursuit dominated by mindless leftism, he depicts veteran labor historians and their acolytes as having exchanged their true calling (the study of industrial labor) for a trendy fascination with "identities and injustice, insistent on workers' 'agency' in the 'larger social and political culture,' but ignorant of industry's engineering. ... As they brought a second or third Thompsonite generation into modern labor history, instead of teaching the new young about industrial work, they have taught them about 'constructions,' representations,' and 'semiotic challenges" as "blessed by Edward Said" and Joan Scott. ${ }^{16}$

Clearly all scholars have a right to their own opinions, and more than a few specialists might agree with one or another of Womack's complaints. Yet none would confuse his reckless generalizations for even a semiaccurate account of our increasingly pluralistic field. Moreover, Womack's strongly-expressed opinions are undermined by his frequent resort to sarcasm, exaggeration, and rhetorical overkill. Are contemporary labor historians really "all in thrall to Thompson, Gutman, and a now thoroughly Thompson/Gutmanized [sic] Montgomery [emphasis added]"? ${ }^{17}$ On some level, all those in a given field are influenced by their predecessors, but responsible scholarly argument hinges on the delineation of the nature and variation of that influence and its shifts through time. And are "Thompson" and "Gutman," with their

zation of American Historians meeting, where else?)" (269). Yet his proclaimed resistance to any rethinking of labor history appears to be a case of "damned if you do, damned if you don't" because his JHS article itself refers to "the shrinkage of old-fashioned industry, the old-fashioned working class, and the old-time labor movement" (272). So the question might be posed: is it really advisable or practical for the field to embark on a struggle to the death to preserve an "old-fashioned" or "old-time" labor history? Regardless of area of geographic specialization, labor history practitioners today offer a common answer and it is not to throw out the baby with the bathwater (as Womack suggests). A 2006 assessment of the Latin American and Caribbean field suggests that "the key to future advances is not to abandon or replace but rather to add to and expand the boundaries of what we define as our objects of study. This can be done by incorporating new theoretical problematics and empirical foci as well as through the application of our existing methods of analysis to subjects beyond our current core concerns." French, "The Laboring and Middle-Class Peoples of Latin America and the Caribbean: Historical Trajectories and New Research Directions," in Global Labour History: A State of the Art, ed. Jan Lucassen (Bern: Peter Lang, 2006), 329. Interestingly enough, the U.S. union movement has also been engaged in a profound rethinking that parallels the newest configuration of the labor history field, including an enhanced attention to women, racial and ethnic minorities, immigrants, and even gays and lesbians.

I5. Womack, "Doing," 269, 279. Even if the field was styling itself a "general history of injustice," the criticism seems arbitrary given Womack's 1983 discussion of the pedagogical role of history, which "can show that everybody hurts ... [and] it seems to me that teaching about pain is the most important thing history can do... [It] teaches that people who really lived went through certain pain, which would have hurt the reader as badly as it hurts them." Judith Evans, "John Womack" (interview), in Visions of History: Interviews with E. P. Thompson et al., ed. MARHO [the Radical Historians Organization] [New York: Pantheon, I983], 260; this observation originates with David McCreery.

I6. Womack, "Doing," 275, 280, 274.

I7. Womack, "Doing," 270. 
rightly influential work, really to be treated as self-evidently negative labels? And what does it mean to conjoin the names of these two very different scholars and arbitrarily apply it to a third distinctive one? Even if it was granted that Montgomery has fallen away from some original state of grace, no evidence of the shift is provided or proof that it derives from the belated influence of his contemporaries E. P. Thompson and Herbert Gutman, by now deceased.

Rather than seeking an opening for dialogue, Womack singles out for special attack those, like Leon Fink, who have called for more "analysis of changing work processes and managerial structures as well as the felt experience of work" and attention to "the basic history of work and occupations." 18 The very fact that the program directed by Fink at the University of Illinois at Chicago includes a course on technology, another possible opening, is met with sarcasm ("bless that professor"). Womack then moves to his crowning put-down: that Fink "evidently cannot tell the difference between work and the experience of it, or the difference between industrial and other work." ${ }^{19}$ A similar attack is launched against the authors of this article. Since Womack is aware of our combined sixty years studying Brazilian and Argentine labor history, what does he gain by saying that we "evidently have no idea what industrial work is: technical, collective, complex"? And given that many of those years have been spent studying two communities and their respective industries (meatpacking in Berisso and autoworkers in the ABC region of Sao Paulo), does it make sense to claim that we "will listen to how sausage is made but resist knowing how the factory ran (or that some workers held better positions than others in keeping the place running or shut it down)"? 20

After such stunning violations of collegiality and tactical common sense, the reader is left with an illogical and oddly personalized grievance. Fink and his collaborators, Womack sniffs, "will not have it in their house, [that is,] a vocabulary or grammar for discourse on the human technical divisions in industrial production" of the sort he seeks to produce. ${ }^{21}$ And in the case of French and James, he claims - against a two-decade history of our attempts to solicit his participation in the Latin American Labor History Conference-that we "would (consistent with their principles) have to denounce" what he proposes to do. ${ }^{22}$ A self-imposed isolation is thus improbably explained as a rejection by others, and Womack's failure to engage with a scholarly community, bound by a common ethic, is presented as a defense of principle rather than a loss to his own scholarship and ours.

Womack backs up his authoritative-sounding pronouncements with the bad habits accumulated over fifty years in a profession he once analogized to monastic life

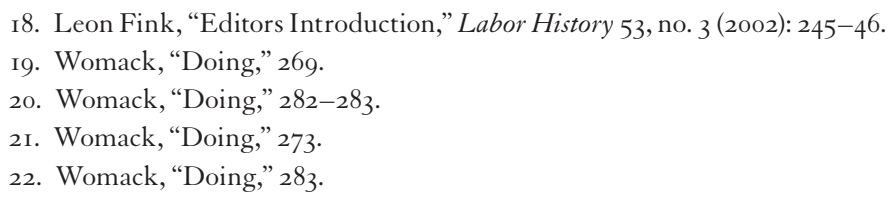


with its vices of "petty bitchiness and trivializing malice." ${ }^{23}$ Hence, the scholarly pretentiousness of providing his own translations for Marx, Gramsci, and St. Simon, even when unnecessary, his discussion of Plato, and his attempt to dazzle the reader with his observation that the Genesis "story is (of course) strongest chanted in the original Hebrew" 24 Moreover, he disdains the elegance of precise and exacting citation and chooses instead to lay down an artillery barrage of endnotes. While some are meaninglessly detailed with dozens of individual pages cited from a given book or article, Womack is just as likely to dump armfuls of distantly related books into a single endnote with no explanation of what they have to do with each other or the text (a case of citation as display presumed to shore up his authority). Of greatest concern, however, is the frequency with which broad and controversial claims are advanced for which no evidence at all is provided. This is particularly true about the ad hominem attacks in which he postulates bad motives and demeaning cultural and political explanations for intellectual developments of which he disapproves. ${ }^{25}$ Womack also routinely blurs the lines between labor history and all that he disdains in the direction of the historical discipline as a whole, including his former Harvard colleague Simon Schama. ${ }^{26}$

Womack's tone of Olympian disdain coexists with rhetorical devices that preemptively delegitimize the intellectual work of others. Through asides, such as "again, I swear" or "honest to God," he takes the "sensible" reader into his confidence as if to say: isn't it amazing that these people actually believe this nonsense? At other moments, he simply resorts to apodictic assertion, as with his claim that his interpretation of Gramsci is self-evidently the only legitimate one. Nor should his clear narrative arc from enchantment to bitterness be taken at face value. He posits a break with his first love, E. P. Thompson, as central to his narrative of disillusionment, but even in his foolish youth Womack was never the infatuated Thompsonian he claims to have been in 2005. His earliest declared inspiration was the Karl Marx of the first volume of Capital and a book by historical sociologist Harry Braverman, Labor and Monopoly Capital, that he fails to even mention in 2005. In 1979, the latter

23. Evans, "John Womack" (interview), 260.

24. Womack, "Doing," 284, 288, 29I-292, 27I; on 280, he twits U.S. labor historians for having read Gramsci only in English.

25. Womack, "Doing," offers a multitude of these insulting speculations: unmoored claims about what is alleged to be the political coordinates of a generation in terms of their dreams, fantasies, and views (276, 280); their surrender to the capitalist marketplace (270); that they can not imagine "a technical story of industrial production that would not bore them senseless and be a complete downer in "the intellectual marketplace"" $(272-73)$; or that they are driven by material motivations ("very few such historians could expect to pay their bills doing histories of labor or work, much less industrial work") leading them to choose more attractive and lucrative themes, thus surrendering to a debased U.S. culture of leisure, shopping, and so on $(272-73)$.

26. Womack, "Doing," 278 , offers statements about the study of work in the United States that slide into a set of complaints, including nonbelief in reality, yet the endnote does not include a single labor historian $(294 \mathrm{n} 78)$. For the snide comment on a former colleague, see his attack on "the formidable Gen. Reader (if not watching Simon Schama re-runs)" (267-68). 
was declared "a virtual handbook for research on recent working-class history" by Womack, who sagely advised that "anyone interested in the history of work or workers should learn its argument cold."

Toward the end of the JHS piece, Womack extends his attack to " "progressive' U.S. historians of Latin America” who, by his account, have adhered en masse to cultural and subaltern studies. His colleagues in his own area of specialization, he begins, will be even more resistant to his project than the run-of-the-mill U.S. labor historians he has earlier derided. ${ }^{28}$ He ends this section by saying "round and round, in their diligently subalternist rites, they would continually turn (thinking it their cultural turn)," which is followed by what is meant to be an intimidating display of menacing erudition: they continually return "to their old, unconsciously inherited, still unrecognized (so still unexamined) often contradictory assumptions from Parsonian functionalism, Popperite methodological individualism, Cooleyian symbolic interactionism, and Goffmanite ethnomethodology." Beyond the incoherent hodgepodge of improbable alleged influences (plus subaltern studies), Womack marshals not a single scrap of evidence to link any of these to a single work by the diverse historians he criticizes, while the weasel words "unconsciously inherited" and "unrecognized" suggest that assertion is his only recourse, not evidence. To add insult to injury, he goes on to project, once again, what is inside their/our heads: these absurd tribal rites and intellectual confusion have a single aim: "to save their [concept of] 'culture' and avoid seeing how work actually works in the organization of industrial workers." ${ }^{29}$ Beyond the murkiness of "how work actually works," this is ad hominem argument at its sloppiest and most embarrassing.

27. Womack, "The Historiography of Mexican Labor," 752-53. He ends his 1979 article by proposing the creation of two new academics chairs, one for "the History of Technology in Mexico, and one for the History of Labor and Workers in Mexico." In this earlier and more sensible version of his current interests, he defined the history of technology as subordinate to the latter, "which after all is the mother subject" $(755-56)$.

28. Womack, "Doing," 279. Contrary to Womack's aggrieved sense of being set upon, the "'progressive' U.S. historians of Latin America" he attacks have routinely gone out of their way to avoid conflict with their powerful senior colleague. Hence the surprisingly mild response by the Yale Mexicanist Gil Joseph to an even more unbridled I999 conference paper by Womack that served as the basis for the $2005 \mathrm{JHS}$ essay. Although not a labor historian, Joseph hastened to find some area of agreement by saying that "Womack was certainly correct about the need to reverse the trend away from research on the work process; it is his disparagement of those labor historians that do cultural history tout court that seems cause for alarm." "Reclaiming 'the Political' at the Turn of the Millennium," in Reclaiming the Political in Latin American History: Essays from the North, ed. Gilbert M. Joseph (Durham, NC: Duke University Press, 200I), I5. Womack responded to this temporizing with a fulminating condemnation of the edited book in which this olive branch was proffered. See his review in Hispanic American Historical Review 83 (2003): 374-75.

29. Womack, "Doing," 292. 


\section{Historiographical Essay as Failed Bildungsroman}

Womack sets himself up as a stern judge of quality in the JHS article and is much given to distributing demerits while stingy with praise. ${ }^{30}$ Yet despite moments of the old eloquence, the essay contains much that appears odd and out of place. For one thing, there is not a single subheading in the twenty-nine pages of text, and its meandering quality reflects the absence of a carefully specified overarching argument. The most distinctive element, however, is the inclusion of a first-person narrative account of what he has learned from his attempt to write about Veracruz workers. Indeed, the second paragraph begins, "In I968 I started research on a history of industrial workers in Veracruz" but soon "began studying industrial companies in Veracruz, . . . at which I spent as much archival time as I did studying workers for the next ten years." By I980, "I decided I had done enough research ... [and] drafted chapters on Mexico's development and Veracruz's industrial enterprises." He next sought to tackle the laboring lives of workers, "but I [simply] could not get my chapter on work right." As he explains, two years were spent working up a narrative "of the work job by job, department by department" among railroad and dockworkers, "which proved much harder than I had expected." As he wrestled with the challenge, Womack expanded the scope of his coverage to additional industries: "one chapter grew into several, for each industry took its own, and industry by industry they grew severally into a very odd project," so by the time "I quit grubbing [it] took me almost twenty years on the calendar." ${ }^{1}$

As the research sprawled, Womack reports adopting a radically different approach from all that was being done in the booming labor history field. "From a constant effort at abstraction," he undertook "a deliberate turn away from culture and class, in order to concentrate strictly on production." "I wanted to see" industry "with an engineer's eye .. : work = Fs, force times space" (?). ${ }^{32}$ At this point, Womack ruefully notes that his growing obsession might lead "an innocent reader ... [to] wonder, among so many concrete details, ... where the analysis or the abstraction was." His hope, he tells us, was that a focus on each industry's "necessary mechanical, manual, and men-

30. While few win laurels for excellence, Womack is surprisingly ungenerous and given to misleading caveats, even in the case of one of his most talented Harvard graduate students, James Brennan. In "Doing," 264, he describes the author of the superb monograph The Labor Wars of Córdoba, 1955-1976: Ideology, Work, and Labor Politics in an Argentine Industrial City (Cambridge: Harvard University Press, I994) as one of those who "professed to take technical factors seriously." Yet while praising him for offering a "concise, precise explanation" of strategic power, he then twits his former student for failing to address inter-industry differences - matters that are, in fact, addressed in Brennan's book as well as in a relevant article not cited by Womack. See Brennan's "Industrial Sectors and Union Politics in Latin American Labor Movements: Light and Power Workers in Argentina and Mexico," Latin American Research Review 30, no. I (I995): 39-68. This likely reflects what Womack perceives as his former student's "defection” from his own strident sectarianism; for a fuller discussion of Brennan's work, see French, "The Laboring and Middle-Class Peoples," 318-22.

31. Womack, "Doing," 256, 259, 26r.

32. Womack, "Doing," 26r, 263. 
tal details" would allow him to "tell in each industry which positions were strategic." 33 Discussing his then no-longer-so-young self, he reports finding little enlightenment from the work of those who were publishing while he privately ruminated. ${ }^{34}$

Until this point, Womack's essay follows the format of a bildungsroman, a moral tale or an ethical parable of the transition from youth to maturity that ends in the character's acquisition of wisdom and knowledge. And Womack will finally report the requisite personal breakthrough as having occurred in 1994 when he taught a Harvard course on the history of Mexican industries and industrial labor for the first time [sic]. The eureka passage reads as follows: "I had to conceive of the workers industrially, in the technical divisions and integrations of their labor... This was my break. Before long I had found new terms for industrial workers' connections at work, and it seemed to me imperative to finish my abstract histories in all of their stationary, motive, moving, dead, and live details they required." 35 In a very real sense, Womack's excursion into the historiography was secondary to a personal quest that lead to this moment of hard-earned wisdom on the part of a now-fully matured man.

Yet it is precisely at this highpoint in his pursuit of self-knowledge that Womack betrays the essential requirements of the narrative genre he has adopted, perhaps unwittingly. Given his account of a hard fought struggle to achieve wisdom, the reader expects him to share the new vocabulary and concepts resulting from this intellectual epiphany, while proving its worth in solving shared problems in the field. The reader's expectations, however, are disappointed, and this suggests unexpected difficulties in operationalizing the intellectual breakthrough he claims to have achieved eleven years earlier. Most surprising of all, the very next paragraph begins with a rhetorical question full of bathos: "But who would care? Any fool culturally or professionally awake knows that for twenty years or more the hot historical issues of Western Civilization have been race, gender, ethnicity, sex, heroes, and signs, and now, finally, right there up front, 'self.' Why on earth would anyone now (or still) try to do an industrial sort of history, of modern industrial work?"36

From this point forward, the $J H S$ article is marked by a radical shift in tone: the failure is not Womack's but that of the society, the profession, and a younger generation of labor historians perverted by their elders. His essay now gains in volume as

33. Womack, “Doing," 262.

34. Harvard sources provide some idea of the scope of his evidentiary base, and what we see does not seem overwhelming in terms of scale. We know that his manually gathered factory employment records (fifty boxes of five hundred forms each) were being converted to an electronic database format in 2oor, and that he and his assistants recorded 8o hours of interviews in Veracruz, which were to be transcribed in 2004. "Conversion of Data Collected on the Industrial Working Class of Veracruz, Mexico, I88o-I940 into an Electronic Data Base," Rockefeller Center faculty research grant in 20or; Ken Gewert, "Losing the Hiss, Scratches, and Din of Traffic," Harvard University Gazette, May I3, 2004. Given that these types of sources have been used by others, Womack might have escaped isolation by entering into dialogue on the methodological questions involved.

35. Womack, "Doing," 266.

36. Womack, “Doing," 266. 
he indulges in baseless abuse: “The history of 'work,' especially 'industrial work,' now evokes physical expressions of boredom, even aversion" on the part of labor historians, who treat it as a "dreary subject." ${ }^{37}$ Yet there are some strange elements to his screed. Echoing typical culture wars' rhetoric, he complains that "scholars now know vastly more about race, gender or sex than they do about work" yet give "no sign that they could ever have enough scholarship about bodies in representation or erotic stimulation." In a snide aside, he notes that "it is historically as well as naturally interesting that the species would die out much faster without work than it would without any copulation." 38 One can only feel embarrassment at the absurdity of this arbitrary thought experiment, which postulates a relative time to extinction based on no work or no sex, because one could just as well observe that no food would produce the same result even faster.

To summarize our argument so far, Womack's JHS article has the apparatus of an historiographical intervention, but not its spirit or ethics, while the confessional signposts of the bildungsroman are present, although it fails to fulfill that genre's requirements as well. Instead, it appears that Womack, frustrated in the quest for his Holy Grail, has conjured up a chimera and marched off to do battle with the imaginary monsters he believes beleaguer him.

\section{The Origins of Womack's Double Impasse}

The historical materials that document the evolution of his Veracruz project since I968 allow us to better understand Womack's deep-seated anger in 2005. In two I983 interviews, Womack was already acutely aware that fifteen years had passed without publishing what was to have been his second monograph. Chagrined at the difficulties, he confessed to an earlier "unbelievable arrogance" because he had written Zapata when he was "not yet thirty ... [and] I thought, Jesus, it only takes a couple or three years to write a book. My arrogance was this: since I've done peasants, next I'm going to write a book about workers in the revolution" and eventually "my synthesis. I thought I'd crack one off every two or three years. So I started hunting subjects" and chose the I9o6 Rio Blanco massacre of textile workers, long cited as a precursor of the Mexican Revolution. So "I went off to Veracruz to study it." 39

After finishing a I98I-82 Guggenheim fellowship, ${ }^{40}$ Womack was profiled in a 1983 Washington Post article entitled "John Womack's Harvard Marxism: The History Chairman's Respectable Unorthodoxy." ${ }^{11}$ Womack was of interest because the

37. Womack, "Doing," $270,267,272$.

38. Womack, "Doing," 270-27I.

39. Evans, "John Womack" (interview)," 252.

40. Womack explained to the Harvard Crimson that "most [Guggenheim] fellows spend the year writing books," while the reporters went on to note that Womack "finds it impossible to teach and write" at the same time. "I4 Faculty Members Named for Guggenheim Fellowships," Harvard Crimson, April I3, I98I.

4I. James Ladner, "John Womack's Harvard Marxism: The History Chairman's Respectable Unorthodoxy," Washington Post, January i, 1983. 
forty-six year old had just been selected to chair Harvard's history department, despite his status as a self-identified Marxist and Communist. ${ }^{42}$ In his Washington Post interview, Womack seemed more comfortable discussing his politics than his writing pace. While claiming that "I'm grateful that I didn't think [in the I97os], 'Oh, boy, I've got it,' and sit down and whip off a book about Veracruz that I would now be unbearably ashamed of," he did plaintively insist that "I think I've found out stuff that nobody else found out. Not just details, but something about the way things work in a society." Yet despite this claim he could not hide a deeper uncertainty, both personal and professional: "If I can get it done and get it done right, I think it will be a very important book in the field. These guys who engineer hearts and work in molecular biology and so on it takes them a long time, and I think it works the same way in history as it does in other fields. You can't program the discovery of what you don't know," and he predicted that the book might still take fifteen to eighteen more years. ${ }^{43}$

Having passed both of those deadlines by 2005 , Womack was less than honest in the Journal of the Historical Society when he advanced a self-serving explanation: he had embarked upon a difficult and lonely quest to achieve a meta-level insight into some profound notion of the "strategic," idiosyncratically his and his alone. It is clear that John Womack has faced an impasse, but the center of his travails will certainly not be found in the false dichotomy of his title: feelings versus material power. In fact, Womack's conceptual and methodological difficulties are best illuminated through the very terms of the theoretical debates in which he has adopted a ferocious if closeminded stance. As his essay reveals, Harvard's most famous Marxist has long felt trapped in narrative: "The better I did my stories, however, the more they too frustrated me," and his mind simply "could not rest." ${ }^{44}$ Yet his response to thirty years of cumulative anguish is to simply radicalize his declared objective of achieving something higher, something objective, hard, transparent, and transcendent, a standpoint that takes gendered shape in his mind as an idealized god-like "Engineer."

In essence, Womack has suffered grievously from his failure to engage with the rich and complicated intellectual debates about representation, narration, and culture. Is it in fact possible to achieve an unmediated and fully objective comprehension of social reality? Or is knowledge always partial, imperfect, and distorted, because even Womack's cherished technical manuals are expressed through the medium of language? And even if one could achieve un-mediated access to reality, what does it means that our comprehension must be expressed through language and its repertoire

42. In Evans, "John Womack" (interview), 257-58, Womack shied away from the label "radical historian," although he did say that "so far I belong to no party, but I consider my political principles as those of a communist. When it comes to politics, I try to associate myself as much as I can with socialist activities." In 1978 , he helped found the journal Marxist Perspectives and served as coeditor with another controversial "Marxist," Eugene Genovese, although the journal quickly foundered and came to an end a few years later. See Richard S. Blatt, "New Marxist Journal Formed: Womack Will Serve as Co-Editor," Harvard Crimson, May 26, 1978.

43. Ladner, "Harvard Marxism."

44. Womack, "Doing," 293, 262, 265. 
of representational and narrative forms? In this sense, all communication is miscommunication. One has to represent and to narrate, but in doing so one is false to what one is attempting to express because the outside world cannot be represented in all of its infinite detail and uniqueness, much less its passage through time (narration). And finally, what is the impact of the fact that all forms of communication, including language, are inevitably social processes that operate within cultural and linguistic systems which play out within larger economic and political institutions and dynamics of a given society at a given point in time?

In his restless wanderings, John Womack has stubbornly failed to avail himself of the insights that might have helped overcome his paralyzing impasse. In a 1983 interview, for example, he inadvertently revealed the pressure he felt because of the incommensurability between reality and what the historian produces. Having once contemplated "writing, say, five thousand pages on workers in Veracruz," he suggests that he now realizes that "a thousand will be plenty." 45 Yet why does he reject questions of representation and narrative so sharply? It appears that Womack does so because he finds them trendy and faddish, a part of what he thinks of as a "new cultural history" that he rejects. In sharp contrast with this "charming nonsense," ${ }^{46}$ he prefers to style himself a hard-nosed industrial engineer, a practical man of knowledge with no patience for affectation. But in truth these theoretical debates are probing the very conditions that make possible the effectiveness of Womack's writing at his most eloquent. His best writing is found when he forsakes the pretense of being a scientist, a neuro-biologist, or a heart surgeon. He is most moving when he is full of emotion, metaphor, and biblical allegory — when he embraces what representation and writing involve. ${ }^{47}$

His resistance reflects, in part, a positivist strain in his philosophy of history (the more facts the better) marked by a limitless drive for comprehensiveness and some version of perfection. Asked by Judith Evans in 1983 about history as a discipline that, as she put it, "has the sense of being every thing," Womack replied: "Yes, I think that history is everything that ever happened and the infinity of questions about it. There is always bound to be something else that happened that we don't know yet." 48 Yet a price is paid for this unending and unbending ambition, and it leads Womack into a valiant but futile struggle to discover a vocabulary or conceptualization capable of uniting all of the disparate groups of workers he had studied, in all of their multifaceted diversity across a half century or more. Even if unfulfillable, Womack takes

45. Evans, "John Womack" (interview), 260.

46. Womack, "Doing," 278.

47. See Womack, "Doing," 27I, for his discussion of work in Genesis. Or one might cite the cadences of Womack's opening to his Chiapas reader: "Americans tend to think of Mexico as an exotic place, which allows them endless fantasies about it. But Mexico is real. It is a big complicated, vastly Catholic, still deeply-old fashioned, nevertheless largely modern, and largely poor country. . . Mexicans love their country intensely. But for most of them it is a hard place to live, work, or do much good. Of all its hard places, the hardest has long been Chiapas, Mexico's Mississippi." Womack, Rebellion, 3-4.

48. Evans, "John Womack" (interview), 260. 
this ambition to be a mark of personal pride on the part of someone who wishes to be seen not as a man of emotion and feeling but of material power and manly command. The ultimate scientistic utopia sought is, as he puts it in the JHS, to achieve a "physical, industrial objectivity." 49

To give substance to his self-image as engineer, Womack adopts an intellectual process of abstraction or, better put, subtraction that he narrates in the JHS. This analytical procedure represents Womack's attempt to resolve the contradiction between the tools at the historian's disposition, the infinite multiplicity of historical experiences, and the abundance of possible interpretations. It also exemplifies the "objectivist" illusion criticized by Jean-Paul Sartre in the late I950s as characteristic of many "bourgeois" social science disciplines and several variants of "lazy Marxism." ${ }^{50}$ In radically rejecting the subjective dimension of reality (which Womack stylizes as "feelings"), the researcher denies his or her own role in the production of knowledge. This effort to put the researcher "out of the experimental field" involves a refusal to problematize the relationship between the researcher as subject (the 'thinking agent') and the object of his research (whether living human beings or the remnants of past human lives).

This stance "resolves" by fiat the problem posed by the gap between subject and object, and the imperfections of knowledge it inevitably entails. In denying the researcher's own subjectivity, the resulting intellectual product is transmuted into a mystified "objective" knowledge superior to and set apart from the researcher, the researched, and the reader. We can see this procedure in operation with Womack's concept of "strategic position," which is presented as if it were inherent to the "objective" reality being studied. Thus his role is merely to 'unveil' an underlying guiding abstraction - strategic position - that operates above the historical actors, the sum of whose actions and interactions make up the phenomenon being discussed. Thus the abstraction Womack creates is "real," while individuals, their subjectivities, lives, and culture can only be fictions and phantom presences compared to the "deeper" and more "valuable" objective truth "discovered" by the scholar. To use Sartre's terms, Womack has transformed a process, a dynamic relation, into a static thing ("strategic position"); and it is this abstraction whose "logic" is imposed, through an a priori deductive method, upon the localized realities he seeks to analyze. In discussing U.S. social science, Sartre identifies this procedure as a "synthesis of externality" that results from a premature totalization of knowledge and the consequent abolition of real human beings. ${ }^{51}$

Needless to say, this hyper-objectivist method produces "authoritative" discourses, permeated with notions of ineluctable "progress," and cloaks them in the symbolic capital of "Science" (hence, Womack's analogy to heart surgeons and molecular biologists). The result is an abstract, universalistic, and powerfully normative intellectual product that aggressively claims to occupy a value-free high ground of neutral-

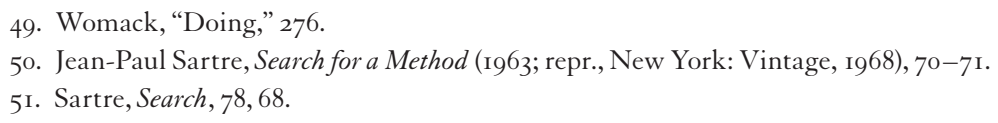


ity and/or objectivity. ${ }^{52}$ In Search for a Method, Sartre discusses the intellectual damage caused by this hyper-objectivist sleight-of-hand. Those so infatuated "can discover nothing by this method of pure exposition. The proof is the fact that they know in advance what they must find." Such a scholar may claim "to discover the object in the historical process and the historical process in the object. In actuality, he substitutes for both alike a collection of abstract considerations," 53 with an accompanying loss of local moorings including, in the case of Womack's Veracruz, the specificities of peripheral industrialization within this particular regional space within Mexico at that time.

The favored posture of Olympian aloofness discourages serious engagement with the intellectual work of others. Whether prompted by "fear or hate or laziness," they read those with whom they disagree by peremptorily rejecting their work out of hand. As Sartre notes, and is clear in Womack's case, the results are predictable: "they literally do not understand a word of what they read." The irony, as Sartre rightly suggests, is that even their own interests would be better served through a more open approach that would allow them "to reject and condemn more precisely, to refute more triumphantly, exactly insofar as they first know what it is they are damning and refuting." 54 Blind to this possibility, all encounters are one-sided and serve merely to confirm an overweening confidence in their own opinions. As the jocular saying goes, "minds are like umbrellas, they work best when they're open" and nothing is more subjective or partial than a Womackian engineer's version of history.

\section{Mired in a Quagmire without a Map: On the Surprising Relevance of Borges}

Putting aside the sound and fury, "Doing Labor History" is haunted by a yearning for something uncontaminated by the messiness of culture and even the concept of the "social." Yet the object of his desire is revealed most clearly through imaginative identification with manly engineers, generals, warriors, and communist central committee members. ${ }^{55}$ And in the very paragraph where he shifts from bildungsroman to generalized invective, Womack poses an odd but immensely revealing rhetorical question: "is what I propose only a Borgesian exercise, a maniac's scheme for an endless, ever updated, ever more complex encyclopedia of industrial archaeology? Could it make any useful sense, now, ever?"

52. The discipline of economics is the quintessential example of hyper-objectivism in contemporary U.S. academic life. Interestingly enough, Womack and some of his associates have in recent years moved into this space, especially economic history, in an effort to find a hospitable home.

53. Sartre, Search, I33, I35.

54. Ibid.

55. In "Doing," 265-66, Womack says he seeks "an engineer's idea of industry and industrial plants like a general's idea of geography and junctions, an industrial map a syndicalist warrior might have drawn for strategically important positions, or which a communist central committee used to decide on strategy." There is a certain implausibility to these identifications on the part of a life-long resident of a particularly august Ivory tower (Womack entered Harvard in 1955 as an eighteen-year-old student and never left). What is more surprising, however, is that a self-styled master strategist like Womack would have chosen to publicly declare war in 2005 on all other published labor historians, a sure formula for defeat. 
It is likely that Womack's invocation of Borges was intended to refer to "On Exactitude in Science," a story about the mapmakers of an ancient empire who, driven by their desire for accuracy, built larger and larger maps. "In time, those Unconscionable Maps no longer satisfied, and the Cartographers Guilds struck a Map of the Empire whose size was that of the empire." Yet their search for scientistic perfection turned out, in the end, to be an illusion and later generations "saw that the vast Map was Useless" and "delivered it up to the Inclemencies of Sun and Winters." 56

Before turning to another Borges story, let us review the past thirty-eight years of John Womack's professional life. In its simplest form, it is the story of how the celebrated author of Zapata and the Mexican Revolution initiated a research project that gradually spun out of control in multiple dimensions. What originated as the story of a single massacre of workers on one date in one place soon grew into a study of two, six or eight additional working-class occupational groups across more than a half century. From there, the young professor took up the study of the industries in which they worked and from the social relations of production set out to study the machines in those industrial workplaces while coming to identify with the engineers who designed their use in production. As it grew in scope and ambition, Womack began to search ever more desperately, but alone, for a powerful and compelling abstraction that would discipline the unruly and ever-increasing multiplicity of facts that he had accumulated. It had to be something big whose grandeur would justify the long wait; the pressure must have been enormous, all the more so with each passing decade.

In the JHS article, Womack emphasizes his quest for the abstraction he has come to call the "'strategic," but a careful reading of two available pieces from his project suggest that he is caught up in the descriptive, awash in details, indeed drowning in them. His thirteen-page 1999 article on "Work in the Moctezuma Brewery" is an entirely empirical account of the mechanics of brewing, and this descriptive bent is also characteristic of his longer 2005 article, published in Mexico, entitled "Technology, Work, and Strategic Positions in the Oil Industry in Mexico, I908-1910." 57 Although covering only two years, the article offers an incredibly detailed reconstruction of the technical aspects of laying oil pipes and building oil tanks. While containing a few interesting insights, the article stands out for its mind-numbing level of detail: the exact dimensions of spacing between rivets, the units in which the rivets were transported, the thickness of pipes, the length of their segments, the weight of hammers, and the exact brands and capacities of boilers and pumps. ${ }^{58}$ The level of

56. Jorge Luis Borges, Collected Fictions, trans. Andrew Hurley (London, New York: Penguin, Vintage 1999), 225 .

57. Womack, "Work”; John Womack Jr., "Tecnología, Trabajo y Posiciones Estratégicas en la Industria Petrolera de México, I9o8-igı,” Boletín: Archivo Histórico de Petróleos Mexicanos 6 (2005): 49-86 (cited from www.economia.unam.mx/amhe/publi/revoz.html). Unable to locate the original Mexican publication in the United States, we draw from an English text by Womack entitled "Technology, Work, and Strategic Positions in the Oil Industry in Mexico: 'Development,' I908-19Io” (October 25, 2004), downloaded from www.economia.unam.mx/amhe/memoria/simposiozo/John\%2oWOMACK\% 20Jr.pdf.

58. For a good example, see the passages in Womack, "Technology," 9. 
detail in Womack's article recalls the character Ireneo Funes depicted by Borges in the story "Funes, the Memorious." 59 What was striking about Funes, we are told, was that "his perception and his memory were infallible... . He remembered the shapes of the clouds in the south at dawn on the zoth of April of I882, and he could compare them in his recollection with the marbled grain in the design of a leather-bound book which he had seen only once, and with the lines in the spray of an oar raised in the Rio Negro on the eve of the battle of Quebracho." ${ }^{\circ 0}$

So Funes enjoyed full dominion over the world of facts in their most indisputable form. "Funes not only remembered every leaf on every tree of every woods, but even every one of the times he had perceived or imagined it." Yet Funes was profoundly dissatisfied with language because of its inadequate representational capacity. He disliked, for example, the fact "that the generic term $d o g$ embraced so many unlike specimens of differing sizes and different forms." ${ }^{61}$ In 2005 Womack expressed similar dissatisfactions with the fact that the word "strategic" or "strategic position" was used in many diverse ways by labor historians, none of which met his standards for exactness. ${ }^{62}$ Or we might cite Womack's lament: "how could I narrate thousands of acts simultaneous and continual, not in a Tolstoyan battle, but making trains run?" 63

As for Funes, far from being an idiot savant, he did understand on some level that "to think is to forget a difference, to generalize, to abstract." This lead Funes to create a system designed to organize his "overly replete world of . . . details, almost continuous details." As the narrator reports, Funes decided "to reduce all his past experience to some seventy thousand recollections, which he would later define numerically." Yet even after deciding upon his objective and method, Funes still was not free because "two considerations dissuaded him: the thought that the task was interminable and the thought that it was useless." ${ }^{64}$ Like Funes, Womack has expressed similar fears: "I hope it doesn't take me longer to figure it out and write this history than it took to happen." ${ }^{65}$ In Borges's story, Funes experienced his extraordi-

59. Jorge Luis Borges, "Funes, the Memorius," Ficciones, trans. Anthony Kerrigan (New York: Grove, I962), I07-I5. There were other similarities between Funes and Womack as well. "Without effort he [Funes] had learned English, Portuguese, Latin,” while Womack's 2005 essay displays his linguistic talents with translations from German, French, and Italian. Borges, "Funes," I I5.

6o. Funes, the narrator notes, once "told me: I have more memories in myself alone than all men have had since the world was a world. And again: My dreams are like your vigils. And again, toward dawn: My memory, sir, is like a garbage disposal." Borges, "Funes," I I 2.

6I. Ibid, II4.

62. Womack's disputatiousness about the use of the word strategic in labor history has a parallel with the larger rationale for Funes's quest for abstraction as it was described by Borges's narrator: "Locke, in the seventeenth century, postulated (and rejected) an impossible idiom in which each individual object, each stone, each bird and branch had an individual name; Funes had once projected an analogous idiom, but he had renounced it as being too general, too ambiguous." Borges, "Funes," II3-I4.

63. Womack, "Doing," 260.

64. Borges, "Funes," I I4-15.

65. Evans, "John Womack" (interview), 252. 
nary mental gifts as a painful curse since he was, like Womack, a "solitary and lucid spectator of a multiform world which was instantaneously and almost intolerably exact." The "unfortunate Ireneo" had few defenses, we are told, against the "heat and pressure" of reality that converged upon him, while Womack has more than once spoken of the writing of history as a monastic form of self-discipline and suffering; as he put it in 1983 , "intellectually, history is unending and incessant. It's more than we can bear." 66

Before we end, let us make clear that neither the authors of this article nor Borges's narrator would deny that the projects of both men, although perhaps "lacking in sense, ... [do] reveal a certain stammering greatness." ${ }^{67}$ Yet the element of pathos is far stronger in the case of John Womack Jr. because he was aware early on that he was contending with powerful internal tendencies that he had to come to fear. We can better understand this dimension of the quagmire in which Womack finds himself if we go back to a story he told an interviewer in 1983 . With admirable selfawareness, Womack said he had briefly contemplated becoming a journalist after receiving his bachelor's degree from Harvard in 1959:

I discovered very quickly that I couldn't write as fast as journalists had to. I couldn't just write that ten cars had been stolen off a certain street last week. I'd have to find out what color they were, if they were all blue, if ten blue cars had been stolen off other streets of the same length, what the pattern was. Pretty soon I'd have an outline for a treatise on car theft while the newspaper just wanted last night's police report. ${ }^{68}$

\section{The Limits of Mechanical Causation in Understanding the Material and Immaterial}

Yet epistemological and theoretical issues must be given equal weight to this Funeslike gift/curse if we are to understand Womack's scholarly dead end. An exegesis of Womack's discussion of our 1997 edited book entitled Gendered Worlds of Latin American Women Workers proves revealing in this regard. At the end of the JHS article, Womack is withering in his attack on the editors' introduction and conclusion while praising five of the nine essays as "admirable" (the editors receive no credit for this happy result). He then offers a larger critique that they "all involve the 'social relations of work,' but nothing of the relations among workers in work, just doing their work." Whether or not "workers in work, just doing their work" is a model of analytical clarity, Womack does offer a clearer definition of his unrealized ambition: to write "abstract histories of industrial work, featuring workers only as labor power." It would thus seem a natural next step for Womack to offer a few observations about what might be lost and gained through subtracting the human element, while drawing suggestive illustrations from the chapters of our book on a very different subject. Instead he ends in a flurry of sarcastic misquotations and jeering, before declaring what he believes to be true about us: that his "analytical abstractions" would be

66. Ibid., 260; Borges, "Funes," I I 4 .

67. Borges, "Funes," II4.

68. Evans, "John Womack" (interview), 248. 
rejected as "deterministic moves against humanity or at least reductionist tricks on humanists." 69

We do indeed have a difference with Womack, but not centered on the straw man he sets forth. Not only are we by no means opposed to abstraction, but we have never denied the importance of the material. Indeed, abstraction-as Funes (and Marx) recognized - is an unavoidable stage in any meaningful process of apprehension of material reality. Rather the issue is what Womack understands by abstraction, what purposes it serves in his project, and the theoretical underpinnings of his abstract method. Here, once his polemical invective is stripped away, the reader of his $J H S$ article finds few useful clues. At times his invocation of the abstracted world of production shorn of the cultural, the social, the political and the ideological — what we have called abstraction by subtraction — seems to resemble a Weberian ideal type. Yet Weber himself was insistent that an ideal type was a heuristic device, "an analytical construct" which "in its conceptual purity ... cannot be found empirically anywhere in reality. It is a utopia." 70 It is the task of historical analysis to measure the usefulness and adequacy of this "utopia" for an understanding of reality, and such analysis was by definition cultural analysis for Weber. It was above all a device for testing theories of historical and social causation.

It is here (and not in some imputed opposition to abstraction for which no evidence is cited) that our differences with Womack can be seen most clearly. Based on an exegesis of his 1979 project description, we criticized Womack in 1997 for positing a "unilateral model of social causation and identity formation ... [in which] a single determining factor is given exclusive sway over the lesser realms of social reproduction and human subjectivity and consciousness."71 In our view at the time, Womack's notion of causation was based on an entirely dichotomous understanding of the relation between the material and the immaterial. ${ }^{72}$ This is no small matter since it leaves Womack with no way of establishing (even if so inclined) the possible linkages between his abstracted utopia of a world of production pared down to its essence and the multiple complimentary and contradictory levels of any complex social formation as it develops historically.

Within the Marxist tradition that Womack has in the past evoked as his own, the nature of such linkages has been a fundamental point of debate. Indeed, Gramsci placed this issue at the center of his attempt to rethink classical Marxism. More recently, theorists like Stuart Hall have attempted to develop an alternative to both overly structuralist and culturalist resolutions of the issue of determination-

69. Womack, "Doing," 283. Despite his claims of resistance to the study of industrial labor, the Latin American labor history field actually has a fine 2003 English-language monograph that executes a comparative multi-industry study of another important Mexican industrial city, Michael D. Snodgrass, Deference and Defiance in Monterrey: Workers, Paternalism, and Revolution in Mexico (Cambridge: Cambridge University Press, 2003).

70. Max Weber, Methodology of the Social Sciences (New York: Free Press, 1949), 84-90.

7I. French and James, "Squaring," 2.

72. Womack's predilection for false dichotomies was illustrated in 1979 when he juxtaposed "explanations from political factors and materialist explanations." Womack, "Historiography," 749. 
through a solution that does not embrace the radical contingency of some poststructuralist thinkers. Hall has called this a theory of articulation, and although Womack is under no obligation to accept this approach, some engagement would seem advisable. Instead, Womack appears entirely unaware of the debate while quibbling with our reference to the "articulation of gender and class." The word we should have used, Womack informs us in characteristically condescending fashion, was "inflection," 73 a claim that is either theoretically naïve or just plain sloppy since the set of theoretical issues associated with articulation are in no way connoted by the word "inflection." As a result of this casual dismissal, Womack is left with an entirely mechanical notion of causation that lacks a dialectical sense of a two-way process through which the broadly material and the immaterial influence each other, rather than the first exclusively dictating the second. ${ }^{74}$

The utility of any analytical and methodological approach can only be judged by its results, and his 2005 article on the oil industry provides discouraging evidence in Womack's case. After discussing John Dunlop at the outset, Womack proceeds to establish which of the groups being studied held "industrially or technically strategic positions" according to his own rigorous definition. Yet despite his profound descriptive understanding of work processes, he arrives at an anticlimactic conclusion: there is no evidence that these groups had exercised their power, whether formally or informally. The best he can do, in the last two paragraphs, is offer "hypothetical answers" about their failure to act as his theory suggests they should. The first possibility, he says, is that these groups may have received some rent based on their strategic leverage, and therefore did not need to do so (although he says he lacks the evidence on "differential compensation" to prove this). Based on "circumstantial evidence," he then offers a second explanation: that these groups, which were composed of U.S. citizens, lacked "social, political, legal, or cultural protection," were easily replaced, and "worked in practically complete social isolation, culturally helpless, incapable of communicating with most of their fellow workers (Mexicans) and subject politically and legally to immediate deportation." In other words, his grand search for the "strategic" ends not with a technical explanation, but with an imprecise and very humdrum social, political, legal, and cultural one. ${ }^{75} \mathrm{He}$ appears to have labored to produce a mouse.

73. Womack, "Doing," 283: "they can 'explore the articulation [sic, for inflection] of gender and class' all they please." On articulation theory, see Ernesto Laclau, "Towards a Theory of Populism," in Politics and Ideology in Marxist Theory: Capitalism, Fascism, Populism (London: NLB, I979), I60-164, and Lawrence Grossberg, "On Postmodernism and Articulation: An Interview with Stuart Hall," Journal of Communication Inquiry Io, no. 2 (1986): 45-60.

74. In "Doing," 282, Womack criticizes the two chapters he likes best in our collection because their authors do not focus on "the technical dependence of their particular workers regardless of skill or gender; [and] both miss its inductance of cultural imperatives, alterations of identity, and pressure to mobilize" (emphasis added). Beyond the implied hierarchy and technological determinism, one might note the implausible breadth of Womack's claim about culture, identity, and mobilization.

75. The very last sentence of Womack's article buries any final pretensions of having discovered a generalizable theory of "strategic positions." He simply reiterates a basic truth, spoken and written by thousands going back to the nineteenth century: "if some workers could use industrial and technical divisions of 


\section{Conclusion: John Dunlop and the Always-Already-Social}

For all its fire and brimstone, Womack's $J H S$ piece ends on a surprisingly plaintive note when he observes that "the details in my studies may seem overwhelming," drawn as they are from his "accumulated welter" of data. Yet he desperately wants the reader to know that "there is a method to them that will, I hope, make them intelligible." This is followed by a final curious declaration that industrial relations (IR) expert John "Dunlop had got the key concept right the first time he wrote his 'theory,' now more than 60 years ago, as labor history, and he kept getting it right ever after." ${ }^{76}$ Had he not been so blind, Womack wishes us to believe, he would long ago have realized that the answer he was seeking had been nearby all along, somewhere off Harvard Square where John Dunlop has taught since I939.

In declaring his identification with an older Harvard colleague, Womack seeks to associate himself with a truly practical man of the world who has exercised power in both the government and private sector throughout his life. ${ }^{77}$ Yet the fact that Womack understands his new hero no better than he did his old ones is suggested by the comments Dunlop offered in a long 2002 interview in the Industrial and Labor Relations Review. What stands out most strikingly are Dunlop's repeated warnings against the very enterprise of abstraction-through-subtraction that John Womack Jr. has indulged in for almost four decades. Even when asked about his own theories, Dunlop emphasizes that "models are very abstract and leave out" so much that "no one should take them too seriously." Asked about fifty years of IR model building, he only grudgingly admits that "at some fairly general, abstract level these models capture important aspects of behaviour. But I have to say that most of this work is an academic exercise, no doubt interesting to those who do it and perhaps of some insight to fellow academics, but they have little to do with reality."78

In terms of Womack's declared ambitions, Dunlop's most poignant answer comes when he is asked to "distill to one page the two or three most important lessons or 'truths' you have learned in the arena of industrial relations over six decades." Given the possibility of opining most grandly, Dunlop's reply is especially relevant to a would-be scientistic engineer who strives to expunge the social as well as the cultural. In listing his number one contribution, Dunlop says: "as I stated in a [I948 book] chapter, 'Any group of human beings associated together for any length of time develops a community in which there are recognized standards of conduct and admitted leaders.' No continuing workplace is ever completely unorganized. These informal relations often underlie more formally structured labor and management organizations. ${ }^{" 79}$ That Dunlop accords such importance to informal social relations is strik-

\footnotetext{
labor against the company, the companies could use social and political divisions of labor against all their workers.” Womack, “Technology," 34, 36-37.

76. Womack, "Doing," 283.

77. Womack, "Doing," 285 ni5.

78. Bruce E. Kaufman, "Reflections on Six Decades in Industrial Relations: An Interview with John

Dunlop," Industrial and Labor Relations Review 55, no. 2 (2002): 327, 333.

79. Kaufman, "Reflections," 336.
} 
ing, precisely because they are so powerfully permeated by all that Womack seeks to exclude, be it cultural, psychological, sociopolitical, racial or ethnic, aged or gendered in nature. As such, Dunlop's sage advice can be seen as a warning to immodest scholars who become dominated by the abstractions they themselves create. In doing so, he tells us, they risk losing contact with the always-already-social dimensions of human existence, be it in a factory or in academic and intellectual life.

The story we have unraveled in this article has an unquestionably tragic dimension. We are dealing, after all, with an extraordinarily talented scholar who once spoke of his desire to write a synthesis of the Mexican Revolution. Unfortunately, John Womack Jr. will in the end never escape from Veracruz, nor will he return in print to Morelos, the site of his early triumph, and all of us will have missed the insights that this brilliant historian might have offered if he had tackled the economics and power politics that converge on and emanate from the Federal District of Mexico City. All in all, we have no doubt that there are travails in "doing labor history," but in the case of the JHS polemic, they are pecurliarly those of John Womack in his lonely and restless wanderings. 